\title{
Biofouling on artificial substrata in Muscat waters
}

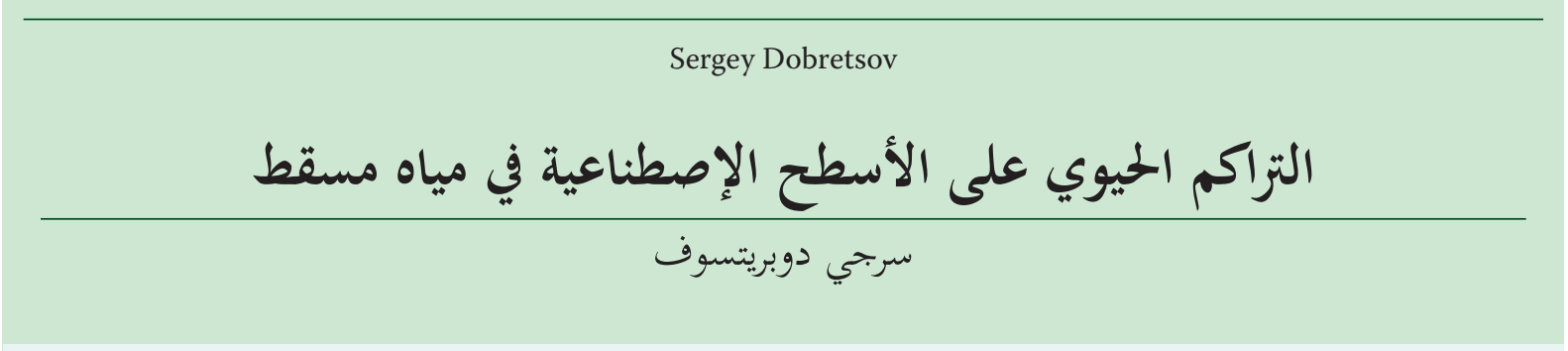

Abstract. Macro-fouling communities developed on acrylic, aluminum, wood and fiberglass panels were investigated after 4 months exposure in Marina Bandar al Rawdah and Marina Shangri La. Wet weight of biofouling was about 2-fold higher in Marina Bandar Rawdah and different communities were formed on the front and back sides of the panels. Differences between communities on different materials were less pronounced. In the second study, wet weight and community composition of macro-fouling communities on ceramic tiles at the depth of $1 \mathrm{~m}$ and $5 \mathrm{~m}$ in Marina Bandar al Rawdah were investigated. During 2008 - 2010, there were no differences between biomass of communities, while in 2011 biomass of macro-fouling was higher on tiles at $5 \mathrm{~m}$. In December 2008 the minimal weight $\left(0 \mathrm{~kg} / \mathrm{m}^{2}\right)$ and in September 2011 the maximal weight $\left(26.3 \mathrm{~kg} / \mathrm{m}^{2}\right)$ of macro-fouling communities were recorded. In total, 27 invertebrate fouling species were found, which mostly (33\%) belonged to phylum Ectoprocta. Three invasive bryozoan (Bugula neritina, Zoobotryon verticillatum and Schizoporella errata) and one invasive tunicate (Ciona intestinalis) species were observed. Overall, this study indicates high biofouling pressure in Muscat marinas and suggests necessity of future studies of fouling communities in Oman waters.

Keywords: biofouling; invasive species; biomass; Sea of Oman.

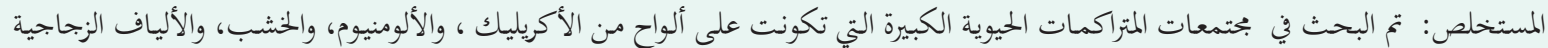

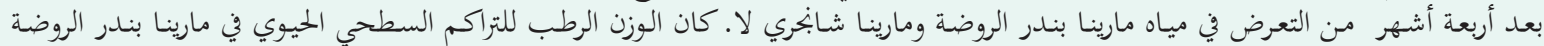

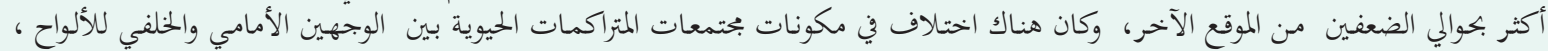

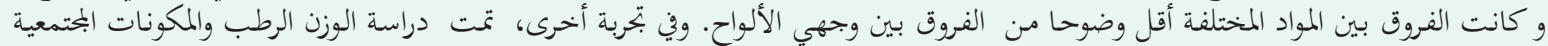

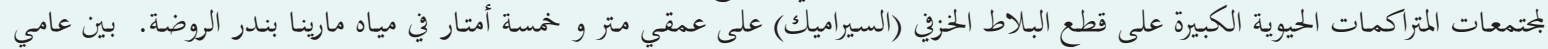

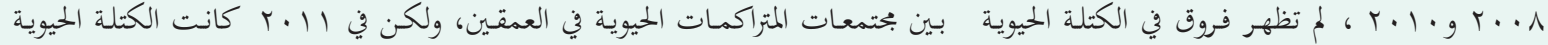

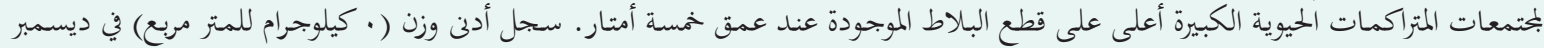

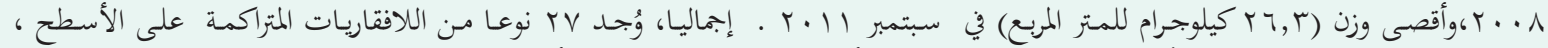

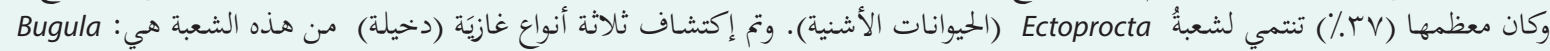
Cliona intestinalis Neritina, Zoobotryon verticillatum, Schizoporella errata

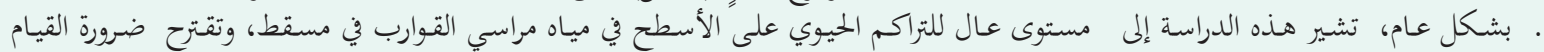

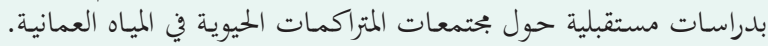

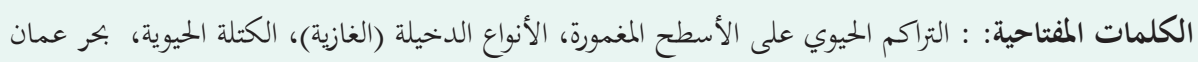

\section{Introduction}

I $\mathrm{n}$ marine environment any undefended natural and man-made substrate is quickly colonized by microand macro-organisms in a process known as "biofouling" (Clare et al. 1992; Wahl et al. 2012). Biofouling is a multi-stage process. The first stage involves the formation of a biofilm mainly composed of bacterial and diatoms incorporated in a polysaccharide matrix (Qian et al. 2007). At the second stage, spores of microalgae and larvae of invertebrates settle on the substrate covered with biofilms (Clare et al. 1992). Microbial biofilms (micro-fouling) either enhance or inhibit settlement of macro-fouling organisms (Dobretsov et al. 2006).

Sergey Dobretsov ( $\square$ ) Sultan Qaboos University, College of Agricultural and Marine Sciences, Dpt. of Marine Science and Fisheries. Box 34,Al-Khod 123. Sultanate of Oman. email: sergey@squ.edu.om
Biofouling caused significant problems for industries and navies alike (Callow and Callow 2002; Schultz et al. 2011). Biofouling reduce speed of boats and ships, clogs aquaculture nets, water intakes and heat exchangers (Okamura et al. 2010; Schultz et al. 2011; Sievers et al. 2014). Additionally, biofouling organisms increase corrosion, shear stress and drag, eventually leading to higher fuel consumption and increased production of $\mathrm{CO}_{2}$ by ships. In order to control and deal with biofouling around the world, countries spend annually more than US\$5 billion (Dobretsov et al. 2006).

Current antifouling methods are based on the usage of toxic metals, such as copper and zinc, and organic compounds, such as Sea Nine (Yebra et al. 2004). These compounds pollute marine environment and are toxic to marine organisms and humans (Ali et al. 2013; Thomas et al. 2002). Due to high environmental risks the use of one of the highly successful antifouling agent - organo- 
tin (TBT) - has been banned globally in 2008 (Guardiola et al. 2012). Therefore, there is a strong need to develop non-toxic or low toxic "environmentally friendly" antifouling solutions.

For the development of a successful antifouling defence one need to investigate occurrence of biofouling species on different materials, depths, and during different seasons. While there is a strong indication that biofouling cause numerous problems for boat and ship owners, aquaculture and desalination plants in Oman, there is limited information about biofouling in Oman waters. It has been shown that the alga Ulva sp. and the barnacle Balanus amphitrite were the major macro-fouling species in Oman waters (Dobretsov et al. 2013). Few publications describe biofouling communities in Arabian Gulf. High diversities of fouling organisms, such as algae, sponges, cnidarians, annelids, arthropods, molluscs and echinoderms, were found on fish cages in Kuwait waters (Mohammad 1976). Another study conducted on the legs of oil platforms in Abu Dhabi demonstrated that the highest biomass of fouling organisms was observed at the depth of $5 \mathrm{~m}$, while the highest number of individuals were found at the surface (Stachowitsch et al. 2002). Not only the exposure depth but also chemical and physical properties of the substratum affect formation of biofouling communities (Connell and Glasby 1999). It was demonstrated that higher densities of macro-fouling organisms were found on black but not on white substrata in Oman waters (Dobretsov et al. 2013). Different macro-fouling communities were formed on wooden and metal substrata (Scheer 1945).

We hypothesized that formation of macro-fouling communities in Oman waters is different and depends on the type of substrata, exposure depth and location. The main aims of this study were: 1) to investigate the formation of macro-fouling communities on acrylic, aluminum, wood and fiberglass panels in two marinas in Muscat waters; 2 ) to study long-term ( $>3$ years) dynamics of macro-fouling communities on ceramic tiles at the depth $1 \mathrm{~m}$ and $5 \mathrm{~m}$ in marina Bandar $\mathrm{Al}$ Rawdah and 3) to identify main macro-fouling species present in Muscat waters.

\section{Materials and methods}

\section{Experimental sites}

This study was conducted at Marina Bandar Al Rawdah $\left(23^{\circ} 34^{\prime} 55^{\prime \prime}\right.$ N $58^{\circ} 36^{\prime} 27^{\prime \prime}$ E) and Marina Shanri La (23 32' $56^{\prime \prime} N 58^{\circ} 39^{\prime} 23^{\prime \prime}$ E), Muscat, Sultanate of Oman. These are semi-closed marinas with limited current (1$10 \mathrm{~cm} / \mathrm{s}$ ) few kilometers apart from each other. Marina Bandar Al Rawdah is relatively old (opened in 1996) and polluted, while Shangri La is a new, unpolluted marina constructed in 2007. During the experiment, the average water temperature was $26.8^{\circ} \mathrm{C}$ and salinity was $35.5 \mathrm{ppt}$. Both marinas have similar temperatures and salinities,
Table 1. List of invertebrate fouling taxa recorded during this study in Muscat waters with their taxonomic position.



as well as amounts of dissolved nutrients. The average depth at the experimental sites for both marinas is about $6 \mathrm{~m}$ at low tides. 


\section{Experimental design}

Two experiments were conducted. In the first study, acrylic, aluminum, wooden and fiberglass panels (size $=250 \times 150 \times 3 \mathrm{~mm})$ were exposed vertically to biofouling at the depth of $1 \mathrm{~m}$ for 4 months (October 2011 - January 2012) in Marina Bandar Al Rawdah and Marina Shanri La. Each experimental set up contained one acrylic, aluminum, wooden and fiberglass panel attached by ties to a PVC pipe. Pipes were attached to marina pontoons by ropes. The distance between the set ups was $\sim 1 \mathrm{~m}$. There were 3 replicated set-ups in this experiment. At the end of experiment, the panels were retrieved and brought to the laboratory on ice. Presence of dominant species was recoded. Biofouling was scraped individually from front and back side of each panel using a knife. Wet weight $\pm 0.1 \mathrm{~g}$ of biofouling developed on both sides (front and back) of the panels was recorded. Collected macro-fouling was storied in $70 \%$ alcohol and used for taxonomic identification.

In the second study, ceramic tiles (size $=152 \times 152$ x $5 \mathrm{~mm}$ ) were placed vertically at the depth $1 \mathrm{~m}$ and $5 \mathrm{~m}$ in Marina Bandar Al Rawdah. There were 5 replicated tiles for each depth. Each tile was attached to individual ropes that were tied to pontoons. The distance between ropes was $\sim 0.5 \mathrm{~m}$. Every month tiles were retrieved and their individual wet weight $\pm 0.1 \mathrm{~g}$ and presence of dominant species on the front size of the tiles were recorded. Individual pictures of tiles were made and used for identification of species. Then, tiles were deployed back to the sea. The experiment was conducted from February 2008 till December 2011.

\section{Analysis of data}

Presence of invasive species was detected by analysis of collections and photographs with the help of Global Invasive Species Database (www.issg.org). Bryozoan species were identified by Dr. Andrey Ostrovsky and species of decapods were identified by Dr. Sergey Khvorov.

For each experiment the mean wet weight was calcu-

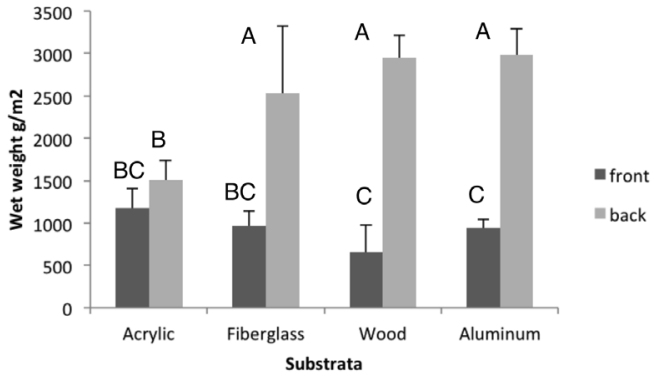

Figure 1. Wet weight (g/m2) of macro-fouling communities developed on acrylic, fiberglass, wooden and aluminum plates exposed for 4 months horizontally at the depth of $1 \mathrm{~m}$ in Marina Shangri La. Data are means +1 standard deviation. Means that are significantly different according to a HSD test (ANOVA: $\mathrm{p}<0.05$ ) are indicated by different letters above the bars.

lated. The data were square root transformed in order to ensure normality of variances. The normality data assumption was verified with the Shapiro-Wilk's test. The effect of the type of substratum, its side and the exposure depth on wet weight of fouling communities was investigated by analysis of variance (ANOVA) followed by a post-hoc HSD test. All calculations were performed using Statistica 11.0 (StatSoft, USA) software. In all cases, the threshold for significance was $5 \%$.

\section{Results}

\section{Experiment 1}

Wet weight of macro-fouling communities developed on front and back sides of acrylic plates in Marina Shangri La was similar to each other (Fig.1). In opposite, weight of biofouling developed on the back side of fiberglass, wooden and aluminum plates was significantly (ANOVA, HSD, $\mathrm{p}<0.05$ ) higher than ones on the front side. It

Table 2. Dominant fouling taxa found on acrylic, fiberglass, wooden and aluminum plates exposed for 4 months horizontally at the depth of $1 \mathrm{~m}$ in Marina Shangri La and Marina Bandar Al Rawdah.

\begin{tabular}{|c|c|c|c|c|}
\hline \multirow{2}{*}{ Location } & \multicolumn{2}{|c|}{ Shangri La } & \multicolumn{2}{|c|}{ Bandar Al-Rawdah } \\
\hline & Front side & Back side & Front side & Back side \\
\hline Acrylic & $\begin{array}{l}\text { Red Algae } \\
\text { Barnacles } \\
\text { Bryzoa }\end{array}$ & $\begin{array}{l}\text { Red and } \\
\text { Green Algae } \\
\text { Barnacles } \\
\text { Bryzoa }\end{array}$ & $\begin{array}{l}\text { Bryozoa } \\
\text { Barnacles } \\
\text { Sponges }\end{array}$ & $\begin{array}{l}\text { Bryozoa } \\
\text { Barnacles } \\
\text { Sponges }\end{array}$ \\
\hline Fiberglass & $\begin{array}{l}\text { Red and green Algae } \\
\text { Barnacles }\end{array}$ & $\begin{array}{l}\text { Red and Green } \\
\text { Algae } \\
\text { Barnacles }\end{array}$ & $\begin{array}{l}\text { Bryozoa } \\
\text { Barnacles } \\
\text { Sponges }\end{array}$ & $\begin{array}{l}\text { Bryozoa } \\
\text { Barnacles } \\
\text { Sponges }\end{array}$ \\
\hline Wood & $\begin{array}{l}\text { Red Algae } \\
\text { Barnacles }\end{array}$ & $\begin{array}{l}\text { Red Algae } \\
\text { Barnacles }\end{array}$ & $\begin{array}{l}\text { Bryozoa } \\
\text { Barnacles }\end{array}$ & $\begin{array}{l}\text { Bryozoa } \\
\text { Barnacles }\end{array}$ \\
\hline Aluminum & $\begin{array}{l}\text { Red Algae } \\
\text { Barnacles }\end{array}$ & $\begin{array}{l}\text { Oysters } \\
\text { Barnacles } \\
\text { Green Algae }\end{array}$ & $\begin{array}{l}\text { Bryozoa } \\
\text { Barnacles }\end{array}$ & $\begin{array}{l}\text { Bryozoa } \\
\text { Barnacles }\end{array}$ \\
\hline
\end{tabular}




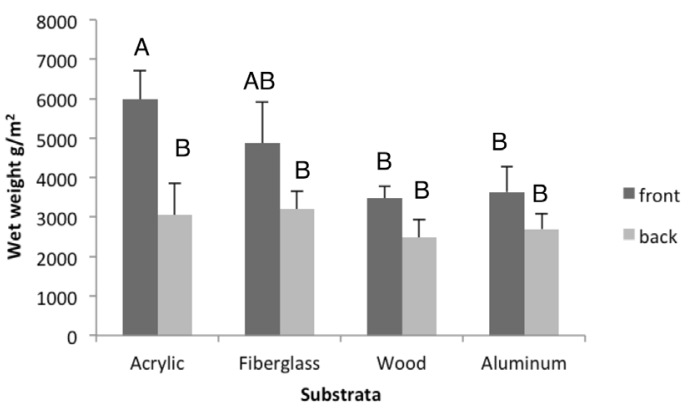

Figure 2. Wet weight (g/m2) of macro-fouling communities developed on acrylic, fiberglass, wooden and aluminum plates exposed for 4 months horizontally at the depth of $1 \mathrm{~m}$ in Marina Bandar Al Rawdah. Data are means +1 standard deviation. Data that are significantly different according to a HSD test (ANOVA: $\mathrm{p}<0.05$ ) are indicated by different letters above the bars.

was easy to scrape biofouling from acrylic, fiberglass and aluminum but not from wooden plates. Wet weight of macro-fouling communities developed on different substrata exposed horizontally in Marina Bandar Al Rawdah was significantly similar (ANOVA, HSD, p>0.05), except front size acrylic and fiberglass substrata (Fig.2). Again, it was difficult to remove biofouling from wooden plates.

Biofouling communities formed on different substrata were slightly different in each marina (Table 1). For example, in marina Shangri La bryozoans were found only on acrylic plates. At the same time, there were drastic differences between biofouling communities formed in both marinas. Red and green algae were found only in marina Shangri La but tunicates Phallusia nigra (Table 2) were observed only in marina Bandar Al Rawdah. Only in marina Shangri La different communities were developed on front and back sides of the plates (Table 1).

\section{Experiment 2}

Wet weight of macro-fouling communities developed on ceramic tiles increased during the first year of study (Fig.3). In December 2008 the minimal weight $(0 \mathrm{~kg} / \mathrm{m} 2)$ of macro-fouling communities was recoded. On September 2011, the highest weight of communities (26.3 $\mathrm{kg} / \mathrm{m} 2$ ) was detected on tiles that exposed to fouling at the depth of $5 \mathrm{~m}$. During first 3 years of the study, there were no significant differences between wet weight of fouling communities developed on tiles at $1 \mathrm{~m}$ and $5 \mathrm{~m}$ (Fig.3). In opposite, in the last year of study, tiles exposed to fouling at $5 \mathrm{~m}$ depth had the highest weight of communities. The average wet biomass on substrata at $1 \mathrm{~m}$ depth was $10.3 \pm 4.1 \mathrm{~kg} / \mathrm{m} 2$, while at $5 \mathrm{~m}$ depth was 14.0 $\pm 6.6 \mathrm{~kg} / \mathrm{m} 2$.

\section{Macro-fouling species}

During this study 7 different phyla of invertebrates were detected (Table 2, Fig. 4). In total, 27 fouling species

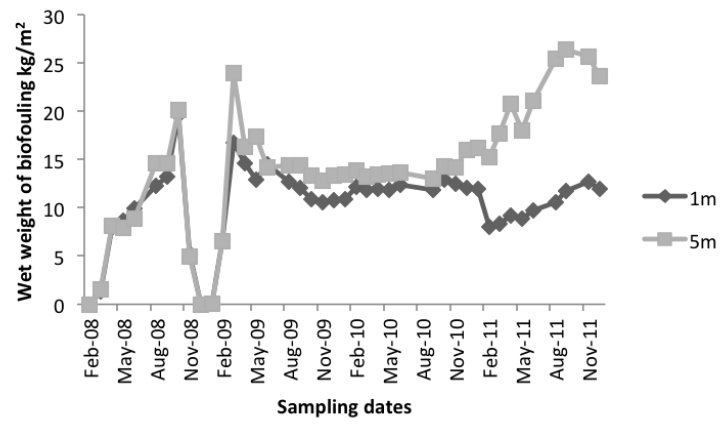

Figure 3. Mean wet weight $(\mathrm{kg} / \mathrm{m} 2)$ of macro-fouling communities developed on ceramic tiles exposed to fouling in Marina Bandar Al Rawdah.

were found. Most of them (33\%) belonged to bryozoa (Phylum Ectoprocta) (Fig.4). Among this group the most dominant were Bugula neritina and Schizoporella errata. B. neritina was mostly present during winter months (December - February), while S. errata dominated during summer and autumn (June - October). In total, 4 invasive species was recorded. Three invasive species $(B$. neritina, Zoobotryon verticillatum and $S$. errata) belong to bryozoans and one ( $C$. intestinalis) belongs to tunicates (Table 2).

\section{Discussion}

Any unprotected substratum in marine environments gets quickly fouled by macro-fouling species (Scheer 1945). Our hypothesis was that fouling pressure on acrylic, aluminum, wood and fiberglass panels would be different. While our data demonstrated different biomass of fouling on some of these substrata (Fig. 1 and 2), we observed that location (Marina Bandar Al Rawdah or Shangri La) and position (front or back) of panels played a major role in the formation of biofouling communities. Higher biomass was recorded on the front size of the panels in Marina Bandar Al Rawdah, while in Marina Shangri La biomass was higher on the back side of vertical panels. This could be due to differences in light intensity on front and back sides of the panels. It has been shown that orientation of the panels and light intensity affected formation of fouling communities (Connell and Glasby 1999; Fairfull and Harriott 1999). Biomass of macro-fouling communities in Marina Bandar $\mathrm{Al}$ Rawdah was more than 2-fold higher than one in Marina Shangri La. This could be explained by differential fouling pressure due to the presence of different species in marinas. While temperature, salinity, currents, and nutrients were similar in both marinas, high organic and inorganic pollution in Marina Bandar Al Rawdah could enhance growth of certain species. It has been shown that aquatic pollution increases success of invasive and fouling species and reduce survival of local species (Crooks et al. 2011; Mayer-Pinto and Junqueira 2003). 


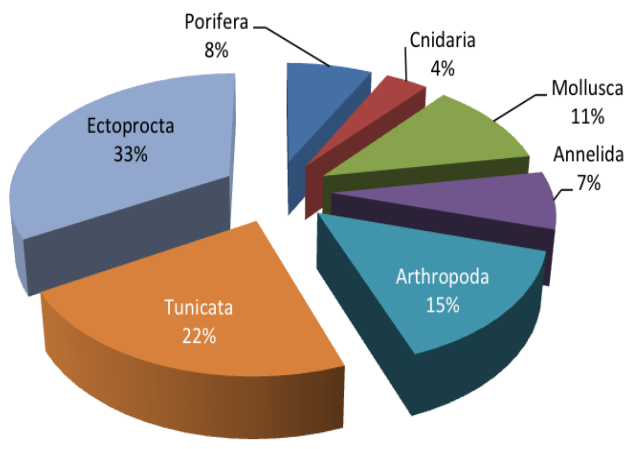

Figure 4. Proportions of macro-fouling taxa recorded during our experiments in Muscat waters.

The average wet biomass of fouling communities detected on ceramic tiles was higher than $10 \mathrm{~kg} / \mathrm{m} 2$. After 4 months, the highest biomass $5.9 \mathrm{~kg} / \mathrm{m} 2$ was detected on acrylic plates in Marina Bandar Al Rawdah. These biomasses are extremely high in comparison with the highest biomass (about $1.5 \mathrm{~kg} / \mathrm{m} 2$ ) recorded on the oil platforms legs in the Gulf region (Stachowitsch et al. 2002). Unfortunately, data about biomass of fouling communities in Iranian waters are not available. Our experiment suggests that biofouling in Muscat and possibly in Oman waters are more intensive than in other Gulf regions. This could lead to more devastating effects on marine installations, desalination plants, ships and equipment working this area.

Experiment 2 conducted in Marina Bandar Al Rawdah showed that only in 2011 biomass of macro-fouling communities was higher on tiles exposed to fouling at $5 \mathrm{~m}$. Previously, the highest biomass of fouling was observed on the oil platform legs in UAE at the depth of $5 \mathrm{~m}$, while highest number of individuals was found at the depth of $0 \mathrm{~m}$ (Stachowitsch et al. 2002). In December 2008 the minimal weight of $0 \mathrm{~kg} / \mathrm{m} 2$ of macro-fouling communities was recorded (Fig. 3). Possibly it was due to harmful algal blooms (HABs) caused by the marine ichthyotoxic dinoflagellate Cochlodinium polykrikoides (Richlen et al. 2010). During HABs of November 2008 - January 2009 the Cochlodinium species were responsible for killing thousands of tons of fish, damaging coral reefs, impacting coastal tourism and desalination plants in the Gulf region (Richlen et al. 2010). While HAB in the Arabian Gulf and the Sea of Oman has lasted for more than eight months till July 2009, biomass of fouling communities is quickly recovered after February 2009. Current study is the first documented impact of HABs on biofouling communities.

During this study 27 species of biofouling invertebrate organisms belonging to 7 phyla were detected (Table 2). Previously, 76 species belonging to algae, sponges, cni- darians, annelids, arthropods, mollusks, echinoderms and chordates were observed on shells of Pinctada fucata in Kuwait waters (Mohammad 1976). Polychaetes, such as Serpula vermicularis, Hydroides chomoceros, and Spirobranchus semperi, constituted more than 55\% of all biofouling species. Presence of sessile filter feeders, such as Porifera, Bivalves, Cirripedia and Ascidia, and small mobile forms, such as Polychaetes and Amphipods, was recorded of the legs of oil platforms in UAE (Stachowitsch et al. 2002). In our study, biofouling communities were dominated by bryozoan species (Phylum Ectoprocta). Differences in fouling species could indicate presence of different fouling species existing in the Gulf and the Sea of Oman.

Our study is the first one that demonstrated presence of invasive species in Oman fouling communities. Alien species include 3 invasive bryozoan (B. neritina, $Z$. verticullatum and S. errata) and one tunicate (C. intestinalis) species (Table 2). Previously, only 11 alien and 6 species with un-identified biostatus were recorded in Oman (www.issg.org). Most of these species were found in terrestrial but not in marine environments. Interestingly, invasive tunicate $C$. intestinalis was not recorded in this part of the world (Therriault and Herborg 2008). Invasive species decrease biodiversity of indigenes communities and have serious impacts on fisheries and aquaculture (Mollo et al. 2008). Most of invasive species spread by ballast waters or by biofouling on ship hulls (Gollasch 2002). While there is no data about the impact of these invasive species on marine communities and fisheries in Oman, their detection is an alarming signal, which shows that early warning and control measures have to be developed in the nearest future.

\section{Acknowledgements}

This work was supported by HM Sultan Qaboos Research Trust Fund SR/AGR/FISH/10/01 and the internal grant, IG/AGR/FISH/12/01. We acknowledge the help of Dr. Andrey Ostrovsky and Dr. Sergey Khvorov in fouling species identification.

\section{References}

Ali, H. R., M. M. Arifin, M. A. Sheikh, N. A. M. Shazili, and Z. Bachok. 2013. "Occurrence and Distribution of Antifouling Biocide Irgarol-1051 in Coastal Waters of Peninsular Malaysia." Marine pollution bulletin 70(1-2): 253-57.

Callow, M. E., and J. E. Callow. 2002. "Marine Biofouling: A Sticky Problem." Biologist (London, England) 49(1): 10-14.

Clare, A. S., D. Rittschof, D. J. Gerhart, and J. S. Maki. 1992. "Molecular Approaches to Nontoxic Antifouling." Invertebrate Reproduction \& Development 22(1-3): 67-76.

Connell, S. D., and T. M. Glasby. 1999. "Do Urban Struc- 
tures Influence Local Abundance and Diversity of Subtidal Epibiota? A Case Study from Sydney Harbour, Australia." Marine Environmental Research 47(4): 373-87.

Crooks, J. A., A. L. Chang, and G. M. Ruiz. 2011. "Aquatic Pollution Increases the Relative Success of Invasive Species." Biological Invasions 13(1): 165-76.

Dobretsov, S., R. M. M. Abed, and C. R. Voolstra. 2013. "The Effect of Surface Colour on the Formation of Marine Micro and Macrofouling Communities." Biofouling 29(6): 617-27.

Dobretsov, S., H.-U. Dahms, and Peri-Yuan Qian. 2006. "Inhibition of Biofouling by Marine Microorganisms and Their Metabolites." Biofouling 22(1-2): 43-54.

Fairfull, S. J. L., and V. J. Harriott. 1999. "Succession, Space and Coral Recruitment in a Subtropical Fouling Community." Marine and Freshwater Research 50(3): 235-42.

Gollasch, S. 2002. “The Importance of Ship Hull Fouling as a Vector of Species Introductions into the North Sea." Biofouling 18(2): 105-21.

Guardiola, F. A., A. Cuesta, J. Meseguer, and M. A. Esteban. 2012. "Risks of Using Antifouling Biocides in Aquaculture." International Journal of Molecular Sciences 13(2): 1541-60.

Mayer-Pinto, M., and A. O. R. Junqueira. 2003. "Effects of Organic Pollution on the Initial Development of Fouling Communities in a Tropical Bay, Brazil." Marine pollution bulletin 46(11): 1495-1503.

Mohammad, M.-B. M. 1976. "Relationship between Biofouling and Growth of the Pearl Oyster Pinctada Fucata (Gould) in Kuwait, Arabian Gulf." Hydrobiologia 51(2): 129-38.

Mollo, E. et al. 2008. "Factors Promoting Marine Invasions: A Chemoecological Approach." Proceedings of the National Academy of Sciences 105(12): 4582-86.

Okamura, D., Y. Mori, T. Hashimoto, and K. Hori. 2010. "Effects of Microbial Degradation of Biofoulants on Microfiltration Membrane Performance in a Membrane Bioreactor." Environmental science \& technology 44(22): 8644-48.

Qian, P. Y., S. C. K. Lau, H. U. Dahms, S. Dobretsov, and T. Harder. 2007. "Marine Biofilms as Mediators of Colonization by Marine Macroorganisms: Implications for Antifouling and Aquaculture." Marine bio- technology (New York, N.Y.) 9(4): 399-410.

Richlen, M. L., S. L. Morton, E. A. Jamali, A. Rajan, and D. M. Anderson. 2010. "The Catastrophic 2008-2009 Red Tide in the Arabian Gulf Region, with Observations on the Identification and Phylogeny of the Fish-Killing Dinoflagellate Cochlodinium Polykrikoides." Harmful Algae 9(2): 163-72.

Scheer, B. T. 1945. "The Development of Marine Fouling Communities." Biological Bulletin 89(1): 103.

Schultz, M. P., J. A. Bendick, E. R. Holm, and W. M. Hertel. 2011. "Economic Impact of Biofouling on a Naval Surface Ship." Biofouling 27(1): 87-98.

Sievers, M., T. Dempster, I. Fitridge, and M. J. Keough. 2014. "Monitoring Biofouling Communities Could Reduce Impacts to Mussel Aquaculture by Allowing Synchronisation of Husbandry Techniques with Peaks in Settlement." Biofouling 30(2): 203-12.

Stachowitsch, M., R. Kikinger, J. Herler, P. Zolda, and E. Geutebrück. 2002. "Offshore Oil Platforms and Fouling Communities in the Southern Arabian Gulf (Abu Dhabi)." Marine Pollution Bulletin 44(9): 853-60.

Therriault, T. W., and L.-M. Herborg. 2008. "Predicting the Potential Distribution of the Vase Tunicate Ciona Intestinalis in Canadian Waters: Informing a Risk Assessment." ICES Journal of Marine Science: Journal du Conseil 65(5): 788-94.

Thomas, K. V., M. McHugh, and M. Waldock. 2002. “Antifouling Paint Booster Biocides in UK Coastal Waters: Inputs, Occurrence and Environmental Fate." Science of The Total Environment 293(1-3): 117-27.

Wahl, M., F. Goecke, A. Labes, S. Dobretsov, and F. Weinberger. 2012. "The Second Skin: Ecological Role of Epibiotic Biofilms on Marine Organisms." Frontiers in microbiology 3: 292.

Yebra, D. M., S. Kiil, and K. Dam-Johansen. 2004. "Antifouling Technology-past, Present and Future Steps towards Efficient and Environmentally Friendly Antifouling Coatings." Progress in Organic Coatings 50(2): 75-104. 